\title{
Characteristics of Accountancy Education
}

\author{
Brisejda Ramaj Zenuni \\ $\mathrm{PhD}$ Candidate at the Department of Accounting, University of Tirana, Faculty of Economy. \\ Lecturer in Financial and Accounting Department, University of Vlora "Ismail Qemali", Faculty of Economy, Vlore, Albania
}

\begin{abstract}
The framework and development of International Education Standards (IES), attention is given to both the content of the IES, moving from guidelines to standards and to the process of their establishment by the International Accountancy Education Standards Board (IAESB). As in all sectors of the global financial infrastructure, benchmarks for accountancy education in countries with very different characteristics have become increasingly important. The IES establish the necessary elements of pre-qualification and postqualification education and training. Conceptual subjects are covered in a Framework for IES with the objectives of the IES, the mission and strategy of the IAESB, the consultative process and, not in the least, the nature, scope and authority of the IES. The roles of learning, education, on-the-job training and off-the-job training are considered. The Framework and the strategic plan of the IAESB both point to the objective of the IES being ultimately being accepted by governments, regulators, academics, accountancy practices and the public. Over the last decade the IES have become increasingly accepted as benchmarks for good practice. The competency framework distinguishes three major areas: general country characteristics, standards for accountancy education, and competency pillars for accountants and auditors. The use of the competency framework makes it possible to present country results in a comparable format that can be used for analysis and evaluation. IES have been used as benchmarks for accountancy education on a country level. Higher level requirements of the IES are discussed, as well as the principles of the benchmarking methodology. Classification criteria for the selection of countries are considered.
\end{abstract}

Keywords: Accounting education, global business, accountants, quality of accounting education

Disciplines Accounting

JEL classification: M40, M41, M48, I22, I23, I24, I25, A23

\section{Introduction}

Quality in higher education generally, and accounting education specifically, has gained increasing international interest over the past two decades. This has been reflected in calls for evidence of quality in curriculum design and student learning outcomes, and increased accountability for performance from key stakeholders. At the same time, the globalisation of higher education has led to increasingly diferent student in accounting (Watty, 2007). The meaning of quality is a complex issue, recent empirical evidence from a study of Australian accounting academics suggests that quality is a process of transformation for students; not a process of compliance to a rigid, quality (Harvey and Green, 1993; Watty, 2006). The qualification, education, training and experience of professional accountants and auditors are of crucial importance for the functioning and developing of the global financial infrastructure.

A wide range of stakeholders, including universities, regulators and standard setters, professional accountancy organizations and accountancy firms as well as issuers of financial reports and users of accounting services depend on their professional expertise and skills. 
Competences and capabilities of accountants and auditors play a key role in the functioning of the international financial infrastructure. The IAESB ${ }^{1}$ which is the successor of the IFAC Education Committee also plays a significant role in the globalization of accounting education standards.

\section{Global Accountancy Education Research}

The IAESB's mission is to serve the public interest by strengthening the worldwide accountancy profession through the development and enhancement of professional accounting education. The IAESB seeks to achieve its mission through the development, adoption, and implementation of International Education Standards ("IESs").

During the last quarter of 2015 and first quarter of 2016, the IAESB conducted a maintenance review of the Framework (2015), Glossary (2015), and suite of 8 IESs. This review considered only drafting changes and was limited to the following:

- Pure terminology changes, matters of language, typographical corrections, or other drafting issues and

- Drafting changes necessary in order to improve consistency, clarity, and accuracy within the body of an IES and between the Framework (2015), Glossary (2015), and the suite of IESs. ${ }^{2}$

The IAESB is currently working to support the adoption and implementation of the extant IESs. Guidance projects include the development of implementation support materials for $^{3}$ :

- Learning Outcomes Approach- the IAESB has developed a suite of guidance material to support the implementation of a learning outcomes approach by those responsible for IPD ${ }^{4}$ professional accounting education programs, CPD 5 programs, and the development of professional competence through practical experience.

- Entry to Professional Accounting Education Programs- The IAESB has developed a suite of guidance material to support the implementation of IES 1, Entry Requirements to Professional Accounting Education Programs (2014), including materials that assist Professional Accountancy Organizations in understanding the multitude of factors that influence an individual's success or failure within a professional accounting education program.

- Professional Competence for Engagement Partners- the IAESB has prepared a Questions \& Answers publication and a webcast series to address questions or issues that might arise on implementation of IES 8, Professional Competence for Engagement Partners Responsible for Audits of Financial Statements (2016) by professional accountancy organizations, public accounting firms, or engagement partners.

The IESs improve the quality of professional accounting education worldwide by prescribing requirements for:

- Entry to professional accounting education programs;

- Initial Professional Development ("IPD") of aspiring professional accountants; and

- Continuing Professional Development (“CPD”) of professional accountants.

\section{Competency Framework for Accountants and Auditors}

A competency framework for accountants and auditors has been developed. The competency framework distinguishes three major areas:

- General country characteristics-define the context in which accountancy education takes place. Attention is given to overall country characteristics (legal system, economic position, region)

- Standards for accountancy education (IES) professional characteristics (professional regulation and recognition)

- And competency pillars for accountants and auditors qualification characteristics (practice rights of accountants and auditors; international recognition of qualifications).

\footnotetext{
${ }^{1}$ IAESB, International Accounting Education Standards Board, International Federation of Accountants, Education

2 Handbook of International Education Pronouncements, 2017 Edition, IAESB

${ }^{3}$ Changes Of Substance From The 2015 Edition Of The Handbook And Recent Developments

${ }^{4}$ Initial Professional Development

${ }^{5}$ Continuing professional Developement
} 
Country Characteristics

Differences between countries

- Cultural background

- Legal system

- Economic position

- Higher education

Country characteristics define the regulatory environment and the structure of accountancy education in a country
Accountancy Education

Core elements of accountancy education

- Professional qualification objective and standards

- Final examination of professional competence

- Professional education

- Practical experience

- General education

\section{International Developments}

Codification based on international developments

- Standards

- Guidelines

- Directives

IES of the IAESB can be used as benchmarks for international comparability and recognition of qualifications

\section{Box 1 Competency Framework}

Sourse: Global Accountancy Education Recognition Study 2012

The use of the competency framework makes it possible to present country results in a comparable format that can be used for analysis and evaluation. IES have been used as benchmarks for accountancy education on a country level.

Higher level requirements of the IES are discussed, as well as the principles of the benchmarking methodology. Classification criteria for the selection of countries are considered. Recognition of the qualifications of accountants and auditors between countries at present largely depends on national regulation. This makes it a challenge to find an objective and transparent method to establish substantial equivalence between qualifications as a basis for mutual recognition agreements.

\section{Box 2 Competency Framework}

\begin{tabular}{|c|c|}
\hline Accountancy Education & Standards and Implementation Guidance \\
\hline Conceptual Framework & IAESB Framework for IES \\
\hline \multicolumn{2}{|l|}{ Pre-Qualification } \\
\hline Entry Requirements & IES 1 - Entry Requirements Professional Accountancy Education \\
\hline \multirow[t]{3}{*}{ Knowledge, Skills and Attitudes } & IES 2 - Content of Professional Accountancy Education \\
\hline & IES 3 - Professional Skills \& General Education \\
\hline & IES 4 - Professional Values, Ethics \& Attitudes \\
\hline Practical Experience & IES 5 - Practical Experience Requirements \\
\hline Assessment & IES 6 - Assessment of Professional Capabilities \& Competence \\
\hline \multicolumn{2}{|l|}{ Post-Qualification } \\
\hline Life-Long Learning & IES 7 - Continuing Professional Development \\
\hline Specialization & IES 8 - Competence Requirements for Audit Professionals \\
\hline
\end{tabular}

Sourse: Global Accountancy Education Recognition Study $2012^{1}$

Characteristics of accountancy education can be used to identify differences between qualifications. They are based on an overview used by International Federation of Accountants (IFAC) for its compliance program for member bodies². Evaluation of the status of accountancy education with its components of qualification, education and training in different countries and regions compared with the requirements of the IES.

${ }^{1}$ National Association of State Boards of Accountancy (NASBA), Professor Dr Gert H. Karreman, Professor Belverd E. Needles Ph.D., CPA, CMA, A.M. Verweij page 8.

2 IFAC, International Federation of Accountants, About IFAC, Membership \& Compliance Program, www.ifac.org 
International mobility of accountants and auditors and the recognition of their qualifications are of global interest. Qualification requirements in most cases are different between countries, but increasingly they are based on International Education Standards (IES) and other applicable regulation.

\section{Characteristics of Accountancy Education}

1. Certification Requirements:

- Is there a program of professional accountancy education?

- Is there a practical experience requirement?

- Is there a final assessment of professional capabilities?

- Is Continuing Professional Development (CPD) mandatory?

2. Providers of Professional Education:

- Professional accountancy organizations?

- Universities, and/or other providers of higher education?

- Government bodies?

3. Responsibility for Education Requirements:

- Government or government agency?

- Government with the accountancy profession?

- Professional accountancy organizations?

- Universities, and/or other providers of higher education?

4. Licensing Requirements for Auditors:

- Academic study?

- Practical experience?

- Licensing examination, and/or final qualifying examination?

- On-going requirements to retain a license (CPD and/or re-examination)?

Box 3

Characteristics of Accountancy Education

\section{Certification Requirements}

Providers

Responsibility

Licensing
Professional accountancy education

Practical experience

Final assessment

Continuing professional development

Professional accountancy organizations

Universities and education institutes

Government

Government

Government with the accountancy profession

Professional accountancy organizations

Universities

Academic study

Practical experience

Licensing examination

Continuing professional development and/or re-examination 


\section{Sourse: National Association of State Boards of Accountancy}

Characteristics of qualifications of accountants and auditors that are relevant for the establishment of substantial equivalence between professional qualifications around the world. Accountancy Profession: Normally when an MRA is established this is based on consideration of substantial equivalence between qualifications. As accountants and auditors function as members of professional organizations, it is important to consider the quality of the profession. A proxy for this is full or associate IFAC membership of a Professional Accountancy Organization (PAO), compliance with IFAC SMOs, regional and global affiliations, and MRAs.

The framework is divided in General Characteristics, Accountancy Education and Competency Pillars. Regional regulation and agreements are considered as part of General Characteristics. The content of Accountancy Education is based on the IES. For comparison between qualifications the last part of the framework is essential in which four Competency Pillars that are based on the IES are distinguished:

Pillar 1, Personal Development: university entrance level and academic study; professional skills and general education; professional values, ethics and attitudes

$>\quad$ Pillar 2, Professional Accountancy Education: accounting, finance and related knowledge; organizational and business knowledge; information technology

$>\quad$ Pillar 3, Professional Development: practical experience requirements; assessment of professional capabilities and competence; continuing professional development

Pillar 4, Competence for Audit Professionals

The competency pillars cover qualification, professional education, practical training and CPD of accountants and auditors. The framework is based on the 'Framework for International Education Standards for Professional Accountants' that is published by the IAESB, and on classification criteria. Use of the framework makes it possible to refer to the most recent version of applicable standards, to update information about countries that are included in the study, and to add new countries in a later stage.

\section{Box 4 Competency Framework}

\begin{tabular}{|c|c|}
\hline \multicolumn{2}{|l|}{ Competency Sub-pillars } \\
\hline \multirow[t]{3}{*}{ Personal Development } & University Entrance \& Exit Level (IES 1 and IES 2) \\
\hline & Professional Skills \& General Education (IES 3) \\
\hline & Professional Values, Ethics \& Attitudes (IES 4) \\
\hline \multirow[t]{3}{*}{ Professional Accountancy Education } & Accountancy, Finance \& Related Knowledge (IES 2) \\
\hline & Organizational \& Business Knowledge (IES 2) \\
\hline & Information Technology (IES 2) \\
\hline \multirow[t]{3}{*}{ Professional Development } & Practical Experience Requirements (IES 5) \\
\hline & Assessment of Professional Capabilities \& Competence (IES 6) \\
\hline & Continuing Professional Development (IES 7) \\
\hline \multirow[t]{3}{*}{ Competence for Auditors Professionals } & Advanced Professional Knowledge (IES 8) \\
\hline & Advanced Professional Skills, Values, Ethics \& Attitudes (IES 8) \\
\hline & Advanced Practical Experience, Assessment \& CPD (IES 8) \\
\hline
\end{tabular}

\section{Core Model of Accountancy Education}

Systems of accountancy education in countries are influenced by the characteristics of the countries that are considered. To help understand differences between countries it is relevant to consider classification criteria. An overview of countries is presented in Table 4.1 In the first column countries are divided in six regions: Asia \& Pacific, Central Europe \& Eurasia combined with Middle East \& North Africa, European Union, Latin America, North America, and Sub Saharan Africa. 


\section{Box 5 Core Model of Accountancy Education}

\begin{tabular}{|c|c|c|}
\hline Accounting in the public interest & $\begin{array}{c}\text { Characteristics of accountancy } \\
\text { education }\end{array}$ & International cooperation \\
\hline $\begin{array}{l}\text { Stakeholder approach to } \\
\text { accountancy education } \\
\text { - Standard setters } \\
\text { - Professional accounting } \\
\text { and auditing bodies } \\
\text { - Government agencies } \\
\text { - Degulators } \\
\text { - Educators } \\
\text { - Investors } \\
\text { Cooperation between stakeholders } \\
\text { is a necessary condition for } \\
\text { accountancy education that is } \\
\text { relevant on the country level and } \\
\text { compliant with international } \\
\text { standards }\end{array}$ & $\begin{array}{c}\text { Certification requirements: } \\
\text { professional accountancy education, } \\
\text { practical experience, final } \\
\text { assessment, CPD } \\
\text { Providers: professional accountancy } \\
\text { organizations, universities and } \\
\text { education institutes, government } \\
\text { Responsibility: government, } \\
\text { government with the profession, } \\
\text { professional accountancy } \\
\text { organization, universities } \\
\text { Licensing: academic study, practical } \\
\text { experience, licensing examination, } \\
\text { CPD and/or re-examination }\end{array}$ & $\begin{array}{l}\text { Global and regional initiatives } \\
\text { - } \quad \text { IAAER academic and } \\
\text { professional partnership } \\
\text { UNCTAD capacity building } \\
\text { initiative } \\
\text { - Regional academic } \\
\text { associations } \\
\text { - Global accountancy firms } \\
\text { and professional } \\
\text { associations } \\
\text { Twinning } \\
\text { International networks play an } \\
\text { important role in achieving } \\
\text { comparability and progress }\end{array}$ \\
\hline
\end{tabular}

Sourse: Global Accountancy Education Recognition Study 2012 (NASBA 2013) ${ }^{1}$

For legal system in the second column of Table 4-1 a distinction is made between common law, civil law and mixed. It is of interest to observe that due to the influence of international standards and regulation the number of systems that have to be considered mixed has increased. However for understanding it may still be relevant to consider the historic background of a country. Attention is asked for the situation in Saudi Arabia and in Canada. Saudi Arabia has an Islamic (sharia) legal system with elements of Egyptian, French, and customary law.

\section{Table 4.1: Country Selection}

\begin{tabular}{|c|c|c|c|}
\hline Country & Lezal & Economic & Information \\
\hline \multicolumn{4}{|l|}{ Asia \& Pacific } \\
\hline Australia & Common law & Innovation & GAE 2002, 2007; ADI \\
\hline Hong Kong & Mixed & Innovation & GAE 2002, 2007: ADI \\
\hline India & Common law & Factor & GAE 2002, 2007: ROSC 2004 \\
\hline Japan & Chill law & Innovation & GAE 2002,2007 \\
\hline Malaysia & Mixed & Efficiency & GAE 2002, 2007: ROSC 2012 \\
\hline New Zealand & Common law & Innovation & GAE 2002, 2007 \\
\hline Pakistan & Common law & Factor & GAE 2002, 2007: ROSC 2005 \\
\hline Singapore & Common law & Innovation & \\
\hline Sri Lanka & Mixed & Factor & ROSC 2004 \\
\hline \multicolumn{4}{|c|}{$\begin{array}{l}\text { Middle East, North Africa, } \\
\text { Central Europe \& Eurasia }\end{array}$} \\
\hline Kazakhstan & Chvil law & Efficiency & ADI: ROSC 2007 \\
\hline Kosovo & Mixed & Not avallable & GAEB 2005; ADI; ROSC 2006 \\
\hline Moldowa & Crvil law & Factor & GAEB 2005: ADI: ROSC 2004 \\
\hline Saudi Arabia & Common law & Factor & GAE 2002, 2007: ADI \\
\hline Serbia & Chill law & Efficiency & GAEB 2005; ADI; ROSC 2005 \\
\hline Turkey & Clvill law & Efficiency & GAE 2002, 2007: ADI; ROSC 2005 \\
\hline \multicolumn{4}{|l|}{ European Union } \\
\hline Crech Republic & Chvil law & Innovation & GAE 2002, 2007: ADI; ROSC 2003 \\
\hline France & Chvil law & Innovation & GAE 2002, 2007: ADI \\
\hline Hunsary & Chill law & Efficiency & GAE 2002, 2007; ROSC 2004 \\
\hline Ireland & Common law & Innovation & \\
\hline Italy & Chvil law & Innovation & ADI \\
\hline Netherlands & Chvil law & Innovation & GAE 2002, 2007; ADI \\
\hline Romania & Chill law & Efficiency & ROSC 2009 \\
\hline Sweden & Clvil law & Innovation & GAE 2002, 2007 \\
\hline United Kingdom & Common law & Innovation & GAE 2002, 2007: ADI \\
\hline
\end{tabular}

1 Global Accountancy Education Recognition Study 2012 (NASBA 2013)Professor Dr Gert H. Karreman Professor Belverd E. Needles Ph.D., CPA, CMA, page 20 


\begin{tabular}{|l|c|c|l|}
\hline Latin America & & & \\
\hline Argentina & Civil law & Efficiency & ROSC 2007 \\
\hline Brazil & Civill law & Efficiency & ADI; ROSC 2005 \\
\hline Chile & Civill law & Efficiency & ROSC 2004 \\
\hline Colombia & Civill law & Efficiency & ROSC 2003 \\
\hline Cuba & Civill law & Not available & \\
\hline El Salvador & Civill law & Efficiency & ADI; ROSC 2005 \\
\hline Mexico & Civill law & Efficiency & GAE 2002, 2007; ADI; ROSC 2004 \\
\hline Peru & Civill law & Efficiency & ROSC 2004 \\
\hline Venezuela & Civill law & Factor & \\
\hline North America & & & \\
\hline Canada & Common law & Innovation & GAE 2002, 2007 \\
\hline USA & Common law & Innovation & GAE 2002, 2007; ADI \\
\hline Sub Saharan Africa & & & \\
\hline Cameroon & Mixed & Factor & \\
\hline Ghana & Mixed & Factor & ROSC 2004 \\
\hline Kenya & Mixed & Factor & GAE 2002, 2007; ROSC 2010 \\
\hline Lesotho & Mixed & Factor & \\
\hline Senegal & Civill law & Factor & ROSC 2005 \\
\hline South Africa & Mixed & Efficiency & GAE 2002, 2007; ADI; ROSC 2003 \\
\hline Tanzania & Common law & Factor & ROSC 2005 \\
\hline Zimbabwe & Mixed & Factor & ROSC 2011 \\
\hline
\end{tabular}

The stage of economic development naturally has a high impact on labor market needs and on priorities for accountancy education. This is also true for the legal system that can have a major impact on accountancy education and the balance between academic and professional approaches. The analysis in this chapter shows that the IES can play an important role in achieving comparability of professional qualifications, education and training of accountants and auditors. However for the consideration of results due attention should be given to the influence of country characteristics.

\section{Recognition of Qualifications}

It is of interest to consider how some major players approach the recognition of qualifications and whether their conclusions are based on applicable international standards for professional qualifications of accountants and auditors. In the analysis three standard setters are considered and three professional conglomerates and one global organization. The standard setters are the International Federation of Accountants (IFAC), the International Accounting Education Standards Board (IAESB), the European Union (EU) and the International Auditing and Assurance Standards Board (IAASB).

IFAC and IAESB: The IFAC Statements of Membership Obligations (SMOs) summarize the requirements for IFAC member bodies. SMO 2 requires compliance with IAESB International Education Standards (IES) but this is only mandatory if the IFAC member body is directly responsible. According to IFAC "globally accepted standards should minimize differences between countries and jurisdictions, thus reducing international differences in the requirements to qualify and work as a professional accountant". IFAC does not address responsibility for qualifications and accepts differences between countries. The IES are promoted as benchmarks; recognition of qualifications between countries is not considered as a specific subject.

$>\quad$ European Union: Qualification requirements for auditors are included in the EU 8th Directive; EU Member States must include the requirements in national law. The requirements cover university entrance level, program subjects relevant for auditors, practical experience in an auditing environment, assessment at university final examination level, and CPD. The EU only regulates auditors in view of their public function; there is no regulation for accountants in the 8th Directive. Each Member State has to establish procedures for the approval of statutory auditors from other Member States. At present an aptitude test is required that is limited to national law and professional rules relevant for auditors. In future it may also be possible for candidates to choose an adaptation period.

IFAC and IAASB: The IAASB is responsible for the ISA. According to ISA 600 a group engagement team has, among others, to obtain an understanding of the component auditor's professional competence. ISA 600 does not refer to applicable international standards on the qualification, education and training of local experts. It can be argued that this creates uncertainty for the selection of benchmarks that can ensure that ISA 600 requirements are met.

There are two major differences between IFAC and EU regulation. The IFAC IES cover competence requirements for accountants and auditors; although the IES are increasingly used as country benchmarks, they are only mandatory when 
a professional accountancy organization is responsible. The EU 8th Directive (EU, 1984) is mandatory for auditors, the position of accountants is not considered; the requirements are implemented in national law for each country in the EU. For consideration outside the EU it is necessary to consider that EU auditor qualifications are considered to be equivalent. The requirements of the 8th Directive are so general that actually major differences between EU countries still exist. This has to be taken into account when recognition of auditor qualifications between EU countries and countries outside the EU is considered. The review of the component auditor's competence required by ISA 600 is not based on consideration of any international standard.

\section{Recognition of Qualifications in Albania}

In Albania, Institute of Authorized Chartered Auditors Albania (IEKA) became a member of the International Federation of Accountants (IFAC) in May 2000. IEKA is also a member of the Federation Internationale des Experts-Comptables Francophone (FIDEF) and the South East European Partnership on Accountanc 2003.

IEKA is a full member, International Federation of Accountants (IFAC), Signed and endorsed the Memorandum of Understanding to International Accounting Standards Board (IASB), Mediterranean Association of Expert-Comptable, and South-east Europe Partnership for Accountancy Development (SEEPAD), Federation of Accountancy professions of Francophone countries. Improving the Existing Educational Requirements in Accordance with IESs, Prepare new regulations on professional training of candidates to complete the accountancy education program, and on continuing professional development of members, improve relevant practical training procedures and assessment in accordance with IESs.

Review existing education programs for candidates and make necessary improvements in accordance with the requirements of the Audit Law, the regulations on professional training, IES 2, Content of Professional Accountancy Education Program and IES 4, Professional Values, Ethics and Attitudes (Completed, September 2010 further, update, ongoing). In cooperation with Albanian universities - IEKA Council will continue to make proposals for reviewing the accounting professional education curricula, especially the part of education that is provided by the Universities (June 2014 ongoingthis has to be harmonized with other changes). Establishing a system of recognition (accreditation) between IEKA and Universities. IESs requirements to be promoted to various Universities in the country. (Completion date January 2017). Update CPD programs of IEKA's members in accordance with the Audit Law requirements, relevant regulations, as well as the requirements of IES 8, Competence Requirements for Audit Professionals.Action Plans are developed by IFAC members and associates to address policy matters identified through their responses to the IFAC. Compliance SelfAssessment Questionnaire. They form part of a continuous process within the IFAC Member Body Compliance Program to support the ongoing development and improvement of the accountancy profession around the world. Action Plans are prepared by members and associates for their own use based on the national frameworks, priorities, and processes and challenges specific to each jurisdiction. As such, they will vary in their objectives, content and level of detail, consistent with their differing national environments and stages of development, and will be subject to periodic review and update. IEKA is in an ongoing process of reviewing the education requirements to ensure that they comply with International Education Standards (IESs), EU statutory audit Directive, the Albanian Audit Law, and to improve the delivery of accountancy education and CPD trainings. IEKA also promotes relevant requirements to Universities.

\section{Conclusion}

In the field work of accountancy development local challenges are faced in a large variety of ways. A distinction can be made between general characteristics of a country in the field of accountancy development, the position of the accountancy profession in a country, and specific considerations for education and training.

local culture and ethics principles of accountancy professionals and local financial markets differ from the international benchmark focused on the 'public interest', which prevents convergence with international (education) practice as this may not (yet) be cost effective and profitable.

The PAO may not have a legal foundation, which usually is the reason for undesired competitive initiatives when for example a PAO show enhancement of its financial position (CPD-activities), which is a waste of human resources and a risk for low quality CPD-activity. 
Where the profession is small, the limited number of professionals prevents development of a sound education system and other necessary requirements like a system of quality control and investigation \& discipline.

Country level development may go slowly (education included) as the PAO faces no authoritative power in important areas of development, creating the necessity of improving its reputation of being the center of excellence (IAESB promulgates IESs through PAOs).

For long term sustainable development it is necessary to encourage change of attitude and mind-set of all stakeholders involved; intellectual assistance usually is necessary. This is a recommendation to start worldwide with accountancy education and training in a harmonized way, but fit for purpose and step by step. A local approach, based on local needs and cultural grounds is unavoidable.

IEKA is in an ongoing process of reviewing the education requirements to ensure that they comply with International Education Standards (IESs), EU statutory audit Directive, the Albanian Audit Law, and to improve the delivery of accountancy education and CPD trainings. IEKA also promotes relevant requirements to Universities.

\section{References}

[1] IAESB, International Accounting Education Standards Board, International Federation of Accountants, Education

[2] Handbook of International Education Pronouncements, 2017 Edition, IAESB

[3] Changes of Substance from the 2015 Edition of the Handbook and Recent Developments

[4] National Association of State Boards of Accountancy (NASBA), Professor Dr Gert H. Karreman, Professor Belverd E. Needles Ph.D., CPA, CMA, A.M. Verweij page 8.

[5] IFAC, International Federation of Accountants, About IFAC, Membership \& Compliance Program, www.ifac.org

[6] Global Accountancy Education Recognition Study 2012 (NASBA 2013)Professor Dr Gert H. Karreman Professor Belverd E. Needles Ph.D., CPA, CMA, page 20

[7] Developing a Global Model of Accounting Education and Examining IES Compliance in Australia, Japan and Sri Lanka Final Report October 23, 2012

[8] "Competency approach to accounting education: A global view" Nishat Abbasi Metropolitan State University of Denver page 7, Journal of Finance and Accountancy.

[9] IAESB, International Accounting Education Standards Board, International Federation of Accountants, Education, www.ifac.org 